Article DOI: https://doi.org/10.35219/efms.2019.1.04

\title{
METHODOLOGICAL LANDMARKS REGARDING THE TEACHING OF THE OINA GAME IN SECONDARY SCHOOLS
}

\author{
Ioan-Sorin GĂLĂȚEANU ${ }^{1}$ \\ Petru GHERVAN ${ }^{2}$ \\ ${ }^{1} \mathrm{PhD}$ student, The State University of Physical Education snd Sports, Chișinău, Rep. of Moldavia \\ soringalateanu@yahoo.com \\ ${ }^{2}$ University professor PhD, "Ştefan cel Mare" University of Suceava, Romania \\ petrug@usv.ro
}

\begin{abstract}
Summary: Oina is a sports game with a limited spread, especially in the rural areas and particularly around some centers with tradition throughout the country. The most recent articles and studies attempt to crystallize their own methodology, oriented towards the modern, global way, but without denying the opportunity to use the analytical method in certain situations, moments or stages of the training process.

Studying the specialty literature, we deduce that the oina game is based on a limited number of research and the learning methodology is based on studies and research done in other sports games. The opinion of the people in the oina field, unanimously accepted, is that at present, the literature regarding this field is incomplete and in fact, it is clearly outrun by the practical side of the problem.

At the level of school education for both physical education classes and the classes in sports circles, we do not find many published studies although, in the schools where the oina game is practiced, there is an intense practical training activity.
\end{abstract}

Key words: oina, Physical Education, gymnasium/secondary school.

\section{Introduction}

The constant updating of the content and forms of manifestation of the efforts to the exigencies of the competition requires an activity of information and research which is necessary in performance oina.

Roată R. (2018, p.66) states that "oina is a game suited for developing all the child's qualities and abilities to include low intensity skills exercises for improving aerobic capacity, to include coordination skills, ability, mobility, agility, some forms of speed manifestation, and sometimes "maximum strength."

In the oina game, the effort is present and it also develops with the specific structures of the game, namely: elements, phases, fundamental systems, rounds, parties and it is also subject to the same requirements of the game essence. The training, a complex process designed to solve all the components of the game in accordance with the competition requirements, will also solve the problems of the effort, in accordance with the game requirements.

In this situation, one can talk regarding the oina game about the specific effort, proper to the other structures of the game: phases, fundamental systems, rounds, parties and competitions. Today, the authentic performance training of the oina teams is achieved with a multidisciplinary participation in teams, precisely with the aim to achieve the objectification of the training and its components in accordance with the competition.
Through its content and forms of manifestation, the effort in the performance oina is closely linked to the development of each phase and each action of the game, because in its essence, in oina game, any error of a single act of play means the loss of the point, or even the loss of the game.

Other data, related to the training effort, in the oina performance, consist of information about its volume, intensity and complexity.

The volume refers to the number of repetitions and the duration of the effort, which in the performance oina can be stretched on a very large scale depending on many factors. The intensity of the effort, specific to the performance, is manifested by the number of executions in time or game units and it provides a great amount of information that can be set up in goals or training sessions.

Researching the complexity of the game and training efforts based on the psychomotricity specific to the performance oina requires an objective evaluation of it, which is often done with the help of video and computers.

\section{Material-method}

In order to carry out the research we used the twoway documenting methods, namely: the method of studying the history of the game and the the specialty literature, used for the knowledge of the ancestors' experience in the oina field and the method of the 
discussions with the specialists, with the purpose to know the current experience and trends in the field.

The aim of the research is to implement a training model at the level of the representative oina school team in the gymnasium cycle and by using some appropriate methods and means to contribute to its efficient growth in the competitions in which it participates.

\section{Discussions}

The teaching of oina ? play in school is done according to the programs developed and approved by the Ministry of Education and National Research, which must be fully respected and completed and the last program, the one of 2017 is the reference.

In the postwar period, oina was not included in the school study but since 1984 the game has been reintroduced in schools for its outstanding qualities. The reintroduction of the oina game was done through the Program of Physical Education and Sports for the Secondary/ (High-school) Education in 1984 approved with the number 35244. After that there appeared other programs which culminated with that from 2017 and they complete each other, at least for the oina game.

The last one in 2017 contains a presentation note, general skills and specific skills and examples of learning activities.

The school curriculum clearly specifies the content of the oina game for the classes in the secondary schools, but for the lessons in the sports circles, we do not find in the school documents any content or necessary practical and methodological guidance which, in our opinion, would be important for spreading the game.

We consider the lack of a rich specialty literature as a brake in spreading the oina game. Here are arguments that have determined us to take into discussion a theme of this kind and allow us to share the experience gained over the years.

Regarding the instructional-educational objectives for the teaching of games, the school curriculum shows the following:

The $1^{\text {st }}$ year of study:

- keeping and protecting the oina ball with one hand and two hands;

- catching the oina ball on the spot, jumping, walking and running;

- throwing the oina ball for batting, passing and

"targeting";

- passing the oina ball from above the shoulder, above the head;

- serving the oina ball standing with the trunk slightly

bent forward;

- batting the ball with the bat;

- targeting the opponent when he is in the square or the triangle, on the spot or in the running;

- running across the lanes;

- blocking (stopping the ball);

- the individual defence;

- entering the game;

- positioning;

- knowledge regarding the rules of the game.

In the $2^{\text {nd }}$ year of study there are introduced game actions on the field, passing the oina ball from above the shoulder, from above the head, from the joint of the elbow, catching and passing the ball in the triangle and in the square, "targeting" the opponent, following that, in the $3^{\text {rd }}$ year, the technical-tactical elements would be more complex such as:

- from balance serving the oina ball standing with the trunk slightly bent forward;

- standing with knees bent (from squatting);

- the catching in the middle;

- caught in the middle on the spot or in running;

- running and stopping across lanes

- game actions in the field: catching and passing the ball in the triangle and in the square "targeting" the opponent;

- the integration of technical-tactical actions in the bilateral game;

- knowledge of arbitration;

- organizing and leading the oina game.

It is noticed in this school curriculum a clear and logical formulation of the competences as well as of the content elements.

This curriculum provides methodological suggestions where there are integrated didactic strategies, the evaluation system, as well as the description of the control tests very well structured on learning levels.

The objectives of physical education in the gymnasium cycle are carried out according to the current program through the following forms of organization:

1 - The Physical Education lesson;

2 - The sports circle or the overall sports.

The sports circle is a form of extracurricular activity that is found in the curricula of both elementary and secondary education, expressed in several formulations.

In secondary education, sports circle classes are regulated by Order 3638/2001 regarding the application of the Educational Framework, Art.6 (2). "In general education, coral and sports activities outside the daily schedule may be organized on Saturdays, too. These activities can be included in the teacher's standard, one hour per week, for each group.

The sports ensemble class does not enter the class/classes schedule, being a sports activity where students from several classes can participate on the basis of some criteria set for each sport discipline at the department level. As a rule, there are granted 4 hours of sports ensemble, having, as a guidance element, the students' major choices, the tradition of the school, and the chair's intentions to participate in certain sports disciplines in cross-country championships.

The physical education lesson is considered the basic form of the physical education activity in school, the appreciation of the pupils' work being made according to the system for verifying and assessing the level of physical and sports training of the pupils.

Undoubtedly, physical education, movement in general, is in a process of regress, if considering the time dedicated to this activity.

In order to meet this obvious regress, the current curriculum provides the organization of the sports circle or sports ensemble with the aim to continue the pupils' training at a higher level in the representative school teams. 
According to the school curriculum, the "sports circle" is organized with 15-20 near-aged pupils from the lower secondary school (the upper secondary - vocational school), on sports branches, separated by sex, no matter the year of study of that school cycle.

The activity takes place outside the classes and aims to involve a number of students in the organized practicing of sports, as well as the formation of teams to participate in school sports competitions.

The instructions regarding the organization and the carrying out of the sports circles include the following:

- in a school, a teacher can receive up to 2 sports circles;

- sports circles are awarded by the school head with the advice of the specialist inspector;

- the lessons are organized for the pupils' activity and not for completing the standard number of hours for the teaching staff;

- the organization of the sports circles is based on the pupils' choice, the school tradition and the teacher's training;

- the existence of a sports circle in a school entails the participation in the competitive system.

The activity within the sports circle lasts two hours, respectively 100 minutes.

By developing the purpose for which the sports circle is organized, we have come to the conclusion that the instructive-educational objectives of these classes are:

a) To continue at a higher level, from the physical and technical point of view, the elements learned in the lessons;

b) To continue the stimulation of the physical development and physical training specific to the sports game;

c) Bilateral practice of sports game within the legal framework.

Taking all these details into account, we have organized a circle of oina, a desire expressed by school students as a result of the tradition of practising this sport. Having a tradition of over 30 years, period of time in which a sports circle has functioned, and having a material base for practicing the oina game, the representative team participates in competitions according to the competition calendar, at traditional friendly meetings with the teams in the county, as well as at various competitions organized by different clubs and associations in the country. Every year we organize a contest highly appreciated by students, namely a demonstrative match between the graduate team and the future team.

As part of our activity in the sports circle, we try to continue at a higher level what we do in physical education lessons, for the initiation in the oina game and for its learning.

As far as the selection of players is concerned, it raises some problems, among which we can mention the addressability and the aim pursued.

I. Drăgan $(1979$, p. 8) says that "addressability is intended for the whole school youth who needs to be dynamically tested, on the one hand to validate the system of physical education and sports meant to ensure a harmonious development of the youth, and on the other hand, to allow talent to be highlighted, as well as the biological exceptions, that are likely to get to the top of the sport pyramid."

Nicu Alexe (1993, p.43) states that "the selection implies a wide-ranging action of conceptual and organizational evaluation on various levels (anamnesis, health diagnosis, the level of growth and physical and functional development, psychic availability, etc.) of some children and junior communities."

Once this selection begins, it lasts for a longer period of time, when transformations can occur and can lead us to a new approach to sports training, a repositioning resulting from new biological features.

In fact, the initial selection is more of a complex investigation that aims to determine the ability or inability to sport.

Instead, the medical-biological selection of performance starts from the biological model (morphological, functional, psychic, etc.).

Roată R. (2018, p. 340) says about the selection in the oina game that "it is made of children eager to practice the oina game in their own school and in the case of clubs / association teams, of the students from several schools. Those who make the selection must have knowledge in this respect and work with physicians and sports psychologists."

It is well known the fact that, nowadays, practising physical education, performance sports, disinterested movement without a material gain, but simply for health purposes, is less common among.

Epuran M. (1976, p. 107) says that "interest in sport can be considered as one of the subjective factors that determine the entry into activity". He further states that "the choice of the child and adolescent for sport is based on certain predominant features of personality (along with somatic and motor skills), (1976, p. 109).

For the sports circle in our school and the formation of the representative team, the logical question is: "Who is part of the representative team? Who is this team made of?"

A great asset in the selection of the future oina players is for us the preference of a very large number of students to practice the oina game, due to the tradition existing in our school for over 30 years. Practically, all our students are in contact with the oina game in various forms (practicing, watching).

However, the mobilization of a large number of students is not possible because of the relatively small number of pupils in our school.

Thus, we made a selection adapted to the existing conditions, but by not sacrificing quality in the established selection criteria. I have appealed to the knowledge of the students in the physical education classes, in terms of the model of the future oina player established in close connection with the factors involved in physical, technical, tactical, psychological and theoretical training.

There were considered both the main criteria and the complementary ones. 
A) Main criteria:

- health status, established by rigorous medical checkup carried out at the beginning of each school year and along the way;

- physical development, established through anthropometric measurements. It was taken into account that the somatic type represents $10 \%$ of the qualities of an oina player, within this percentage, the ideal somatic type looks like: waist $40 \%$; palm size $40 \%$, waist-weight ratio $20 \%$; - for the driving qualities, whose weight is $60 \%$, we have checked the speed of movement, skill, detention, strength;

- the technical-tactical skills were appreciated during the lessons;

- the psychic qualities, which account for $30 \%$ of the qualities of an oina player, were considered by focusing primarily on attention, emotional balance, availability for collaboration, tactical thinking.

B) Complementary criteria:

We mainly considered the following aspects:

- the ability to quickly acquire the technical procedures and the tactical actions; - the capacity of field orientation, the creative spirit, the

- the student's total adhesion to the oina game.

Once the selection problem has been solved, the formation and the cohesion of the team must be taken into consideration. Dragnea C.A. (2006, p.13) states that sports groups go through some elaborated phases in their formation process in order to avoid the dysfunctions that may occur in the future activity of the group.

The task cohesion and that at the social level, a good reputation among the team is a major goal in the coach's desire to make a strong, successful team. While the task cohesion mainly focuses on close cooperation between players to achieve team goals, the social cohesion refers to extra-competitive relationships between players and the technical stuff. Ideally it would be to create a climate of cohesion that includes the task and the inter-human relationships, the consequence being always a strong team spirit, committed to achieving its goals, based on the strong determination to achieve high performances, comradeship and trust among the team members.

For the way in which the team cohesion and its formation can be achieved, some specialists make a series of recommendations to coaches:

to create a team identity;

- to establish the team's goals for awakening a sense of pride;

- to formulate a vision / image for the team. Before the vision becomes reality, it must be assumed by all the players;

- devotion and lack of selfishness must be the main coagulation force in building a team; - all players must be involved in setting team goals and rules;

- to focus on the collective approach to everything that is said and done;
- to be patient and to learn to listen to the players, paying attention not only to what they say, but also to the way they say, to body language, mimics, etc.

- to include players in the decision process;

- to cultivate managerial qualities among players so that everyone should feel that they belong to the team. Regarding the methodological approaches to the teaching of the oina game at the gymnasium level, it is advantageous for a school to have a tradition. Due to the favoring action of the tradition, there is a mutation towards the younger age of the moment when the game is started. The approach to this game from the third and fourth-grade is natural in this situation.

The practice of the oina game has positive influences on the body and the personality of the students. Starting from the idea that:

- in solving the tasks of physical school education, the bilateral play and its phases have a major role and not the analytical, isolated practising of the elements,

- the necessity of accelerating the learning improvement process, imposed by the short time favorable to the practice of the outdoor oina game and by the competition calendar.

I have come to the conclusion that in teaching the oina game it is important to start from the play actions, with which there are achieved both the catching and the beating phases and simultaneously from the bilateral play.

Thus, the pupils who study the oina game play with more realism and are in a position to assimilate from the beginning the gaming elements (technical procedures integrated into individual and collective tactical actions), which solve the phases of attack and defense.

In fact, the problem is a little more complicated in the sense that, trying to play oina from the beginning, the pupil is unable to tie the game due to its characteristics. That is why in the first stage it is compulsory the analytical learning of the basic technical elements such as holding, catching and passing the ball. As soon as these three elements have been acquired, the next step is to practice some of the actions specific to the game in two or in square, introducing the opponent and hence new technical-tactical elements such as the individual targeting and defense. The transition to the bilateral game is accomplished in a particular way through a complete exercise, play on a lane and oina in 6 players.

Concluding, the methodical orientation and the teaching of the oina game in school recommend the use of the global path and it does not deny the use of the analytical path in certain situations of the training process. The alternative use of the two horses must have a logical reasoning from a methodical point of view.

If during the practice of the game or the game phases it is found that a certain technical procedure is insufficiently learned by the students, it will be passed to the analytical practice.

The analytical training should be done by wellselected means, based on the criterion of the maximum efficiency, so that the process can be integrated as soon as possible in the global execution.

We will highlight some methodological and organizational aspects, the effectiveness of which has 
come out of teaching the oina game over the years, and which we will apply to the experiment.

In analyzing the technical elements, from the analytical point of view we used the following way:

- practising the isolated technical element;

- practising the technical element under difficult conditions;

- practising the technical element in play conditions.

For example, learning to catch and pass the ball followed the line:

1. Learning to catch and pass the ball by execution as such;

2. Races between pupils or groups of pupils:

- longer distances passes;

- number of passes in two without dropping the ball;

- triangle passes;

- square passes;

3. Repeating in game conditions:

- the complex exercise;

- the oina game with 6 players;

- the bilateral game.

This way was also used in teaching other technical elements.

The first exercises with all technical elements are executed without taking into account the marking of the playing court.

After a certain amount of time, we pass to the exercises in the playing field for learning at the same time the characteristics of the playing position. Now, it is advisable for the teacher to accompany the learning with explanations related to the playing position.

In exercises for learning to hold, catch and pass the ball as well as to target, the main indication is that not to detach the foot on the side of the throwing arm from the ground at the time of the throw, in order to get the students accustomed to keeping the place.

The exercises of the "shuttle" type, therefore, passes face to face, although they are not typical for the oina game, they have been used due to the organizational valences.

The exercises executed "crescendo" can also be used as heating exercises.

Students need to be aware of the fact that any ball that is dropped gives the opponent the opportunity to organize his defense or to leave the playing area without being targeted.

Targeting is a technical element for finishing the point. There is a need to train as many players as possible to shoot accurately and forcefully.

In exercises for learning to stop the ball, the major part will be represented by the field exercises, with players in positions.

Creating serving-batting couples is very important in the oina game. If in the first phase the purpose is to study the element itself, later it is necessary to take into consideration the training of some couples who are constantly executing the full hitting with the bat. There are required many couple repetitions.

In terms of defense, in order to succeed, the defender has to form his own style that is why he will be interested in encouraging this aspect.
The tactical training must be done with the utmost seriousness because many of the technical elements turn into tactical elements during the play.

The batting players must be trained the following qualities:

- beat the ball;

be good defenders both individually and collectively;

- make the correlation between beating and individual or group running of the players on the aisle.

The exercises are performed so that the groups can run as long as possible on the high and long beats. The following cases will be practiced:

- batting on the return aisle for the group that comes into play and can, this way, run as much as possible on the aisle;

- batting on the aisle for the group of returning players;

-the tactical batting (playing on the corners of the play court near the beating area, on the aisles opposite to the groups' way forward).

Learning these correlations is done in training, in the first phase the aim is to get the theoretical understanding and in the next phase to discover the best players for beating, the right time to beat, the formation of the groups with good and weak defenders.

In the effort to train the team, "for catching", the starting point in the tactical training is the acquiring of the individual tactics through the improvement of the following actions:

- passing the ball to the teammate who is in a more favorable position,

- the fast and surprising targeting only after a good training and only in favorable situations.

Regarding the collective tactics, it was decided to make the players get accustomed to their position in attack, with a doubling of 2, 3 players for the main shooters.

During practising the game, the phases or the sequences, the correctness of the execution must be followed but without exaggerating. The student should be allowed to choose the most convenient form of execution, provided that it is not in flagrant contradiction with the biomechanics of the technical element.

Bompa T.O. and Carrera (2006, p. 73) states that "the key to an effective program is the proper selection of the exercises" and that "the number and the type of the exercises should be chosen according to the age and performance level of the athlete, the needs of the sport and the training phases".

The attractiveness of lessons and training must always be taken into account. These must be varied and exciting. The child likes to stand out when he succeeds something, or to get ambitious when he's wrong. Lessons must be organized in such a way that they can participate with pleasure and thus they will be "won" for the oina game.

As regards the content of teaching the oina game to the representative team of the school, the problem was considered in the spirit of natural continuity. At the level of the classes, the technical element is learned and improved. At the team level, there is no question of 
learning the elements but of using them for tactical purposes.

The content has been systematized depending on the training factors differentiated on the two aspects: offensive, at the catching, and defensive at the batting.

It is very important that the means used to follow all the aspects of the training starting from the physical one, followed by the theoretical, psychological and tactical one and ending with the one specific to the oina game. Rafailescu A., Opriţescu C. (1974, p.13) states that "a hierarchy of these factors according to their importance is not indicated, because each one can at one point have a decisive influence on victory."

\section{Conclusions}

Teaching the oina game to students in lower secondary school confirms that this sport can be taught in good conditions if it has an adequate planning, a correct method and well-chosen means.

The activity in the sports circle during the school year in which the experiment was carried out, confirmed the fact that between the global and the analytical method should be an optimal ratio in the sense that the teaching of the game is done globally, but it doesn't deny the use of the analytical method in certain conditions.

Without an initiation of the fundamental technicaltactical elements of the oina game, the students cannot practise the bilateral game.

The switch to the bilateral game cannot be done directly, but through appropriate means.

Practising the bilateral game facilitates the quick learning and the improvement of some new technical elements.

Using the game of "oina in 6" within the reduced teams solves the problem of the sport competition by organizing a competitive system such as "The School Championship".

Teaching the oina game in class facilitates the finding out and the training of the school team by knowing the students from the point of view of the physical, psychical, technical and tactical qualities.

By teaching the oina game the health indexes are positively influenced, the somatic growth is stimulated and the motoric ability of the students is favorably influenced. In this respect, the oina game can sit alongside the other games that are taught in school to solve the tasks and the objectives of the school physical education.

\section{Bibliography}

1. ***Ordinul nr. 3638/11.04.2001 cu privire la aplicarea Planului-cadru de învățământ pentru clasele I - VIII.

2. ***Educaţia fizică. Curriculum naţional. Chişinău, 2010;

3. ***Programa şcolară pentru Educaţie fizică clasele III-

IV, București, 2014

4.***Programa şcolară pentru disciplina Educaţie fizică şi sport clasele a V-a - a VIII-a, București, 2017.

5.***Programa şcolară pentru Educație fizică clasele IXXII, București, 2009.

6 .***Legea educaţiei naţionale nr. $1 / 2011$, în vigoare de la 09.02.2011

7.***Planuri - cadru de învăţământ, pentru învățământul preuniversitar. Consiliul Naţional pentru Curriculum - Ghid Metodologic, M.E.C. București: Aramis, 1999.
8. Alexe N. Antrenamentul sportiv modern, Bucureşti,Editura Editis, 1993, p.43.

9. Bompa T.O.,Carrera C. Periodizarea antrenamentului sportiv,Curtea de Argeș,Editura Clarus Distribution,2006, p. 73.

10. Dragnea C.A. Elemente de psihologie a grupurilor sportive, București, Editura CD Press,2006, p.13.

11. Drăgan I. Selecția medico-biologică în sport,București, Editura Sport-Turism, 1979, p.8.

12. Epuran M., Psihologia educației fizice, București, Editura Sport-Turism,1976, p.107,109.

13. Rafailescu A., Oprițescu C.,Oina, București, Editura Stadion,1974, p.13)

14. Roată R., Oina, modelarea pregătirii copiilor şi juniorilor,Suceava, Editura Universității Ștefan cel Mare, 2018, p.340).

15. Roată R., Oina, inițierea în jocul de oină, Suceava, Editura Universității Ștefan cel Mare, 2018, p.340). 